\title{
Joint effect of freshwater plume and coastal upwelling on phytoplankton growth off the Changjiang River
}

\author{
Y.-F. Tseng ${ }^{1}$, J. Lin ${ }^{2}$, M. Dai ${ }^{2}$, and S.-J. Kao ${ }^{1,2}$ \\ ${ }^{1}$ Research Center for Environmental Changes, Academia Sinica, Taipei, China \\ ${ }^{2}$ State Key Laboratory of Marine Environmental Science, Xiamen University, Xiamen, China \\ Correspondence to: S.-J. Kao (sjkao@gate.sinica.edu.tw)
}

Received: 11 April 2013 - Published in Biogeosciences Discuss.: 26 June 2013

Revised: 6 December 2013 - Accepted: 12 December 2013 - Published: 28 January 2014

\begin{abstract}
The Changjiang (Yangtze) River discharges vast amount of unbalanced nutrients (dissolved inorganic nitrogen and phosphorus with $\mathrm{N} / \mathrm{P}$ ratio $>80$ in general) into the East China Sea in summer. To study nutrient dynamics and P-stress potential for phytoplankton, a cruise was conducted in the Changjiang plume during summer 2011. With 3-D observations of nutrients, chlorophyll $a$ (Chl $a$ ), and bulk alkaline phosphatase activity (APA), we concluded that the Changjiang Diluted Water and coastal upwelling significantly influenced the horizontal and vertical heterogeneities of phytoplankton P deficiency in the Changjiang plume. Allochthonous APA was detected at nutrient-enriched freshwater end. Excessive $\mathrm{N}(\sim 10$ to $112 \mu \mathrm{M})$ was observed throughout the entire plume surface. In the plume fringe featuring stratification and excess $\mathrm{N}$, diapycnal phosphate supply was blocked and phytoplankton APA was stimulated for growth. We observed an upwelling just attaching to the turbidity front at seaward side where Chl $a$ peaked yet much less APA was detected. An external phosphate supply from subsurface, which promoted phytoplankton growth but inhibited APA, was suggested to be sourced from the Nearshore Kuroshio Branch Current. In the so hydrographically complicated Changjiang plume, phosphate supply instead of its concentration may be more important in determining the expression of APA. Meanwhile, allochthonous APA may also alter the usefulness of APA as a P-stress indicator.
\end{abstract}

\section{Introduction}

Rapid urbanization in past decades along coastlines has introduced massive loadings of nutrients and organics into rivers, causing dramatic changes of nutrient status in adjacent estuarine and coastal ecosystems (Jickells, 1998). These rivers are well known to carry nutritional water with high ratios of dissolved inorganic nitrogen (DIN) to dissolved inorganic phosphorus (DIP), or N/P ratios. Such massive yet disproportionate riverine nutrient input has caused an obvious "excess N" (the concentration of DIN in excess of DIP) phenomenon in nearby estuarine ecosystems (Galloway et al., 2004). Ultimately, the continuing increase in $\mathrm{N}$ loading is potentially going to transfer marine ecosystems from $\mathrm{N}$ limitation to $\mathrm{P}$ limitation. Seasonal $\mathrm{P}$ limitation has become evident in some estuarine and coastal ecosystems (Howarth and Marino, 2006). The altered nutrient dynamics will subsequently influence ecosystem structure and function and threaten the safety of aquatic environments. Evidence also showed that unbalanced nutrient composition might drive harmful algal growth (Varkitzi et al., 2010) and modulate carbon (C) sequestration amount due to the adjustment of cellular $\mathrm{C} / \mathrm{P}$ ratios of plankton living in varying $\mathrm{N} / \mathrm{P}$ conditions (Geider and Roche, 2002). The ambient nutrient concentrations that determine the exchange rate between a cell and its medium may vary along the mixing gradient from river to sea, as well as processes such as uptake, transformation, remineralization, and diapycnal supply. Ecosystems' response to nutrient loading has been demonstrated; however, the information about the dynamic nutrient pattern of excess $\mathrm{N}$ versus the influence of nutrient stoichiometry on phytoplankton growth around riverine plumes and adjacent coastal ecosystems requires more exploration.

Under excess-N conditions, $\mathrm{P}$ generally limits phytoplankton growth in plumes and coastal areas where light is sufficient. $\mathrm{P}$ limitation in ecosystems could be determined by 
surrounding nutrient concentrations coupled with N/P ratios (Krom et al., 1991; Dortch and Whitledge, 1992). However, most phytoplankton species have very high affinity with $\mathrm{N}$ and $\mathrm{P}$; the ambient $\mathrm{N}$ or $\mathrm{P}$ concentration may have been below the analytical detection while growth is ongoing. Recently, a physiological indicator of phytoplankton P deficiency - alkaline phosphatase (AP) activity (APA) - has been widely used (Mather et al., 2008; Duhamel et al., 2010). AP is an inducible extracellular enzyme generally existent in freshwater and marine plankton, which can cleave phosphate from dissolved organic phosphorus (DOP) molecules when surrounding or intracellular phosphate concentration is low (Perry, 1972). Growing evidence has confirmed that phytoplankton can utilize DOP via generating AP under P depletion (Hoppe, 2003). This characteristic makes APA a good indicator of $\mathrm{P}$ stress or $\mathrm{P}$ deficiency of phytoplankton in aquatic ecosystems (Dyhrman and Ruttenberg, 2006; Lomas et al., 2010).

The East China Sea (ECS) is one of the largest marginal seas in the western North Pacific Ocean. According to historical records, the ECS was considered as an N-limited ecosystem as other marine ecosystems (Chen et al., 2001). The Changjiang (CJ) River holds large water discharge (annual mean $\sim 924 \mathrm{~km}^{3} \mathrm{yr}^{-1}$ ) and high nutrient concentrations, serving as the major nutrient source to the ECS (Zhang et al., 2007). Since the 1950 s, rapidly growing anthropogenic activities, such as fertilizer applications, have caused $\sim 8 \times$ increase in $\mathrm{N}$ concentration and fluxes in the CJ River (Wang, 2006). In addition, the CJ River was recorded to be a high N/P ratio system (Liu et al., 2009) and "excess N" was found in the surface water covering more than one-third of the ECS in summer (Wong et al., 1998). Obviously, increased riverine nutrient loads have induced major changes of nutrient stoichiometry in coastal zones (Chai et al., 2006), and it seems that the increasing trend and the expansion of influenced areas are non-stopping. Consequently, vast areas around the CJ River mouth and ECS shelf are suggested to be P-limiting for phytoplankton growth (Harrison et al., 1990; Wang et al., 2003). Likely, such $P$ limitation will be more serious in plume regions during the summer period, when river discharge and productivity are both promoted.

In this study, the Changjiang plume (CJ plume) was selected to explore the consistency between chemical and physiological indicators, such as phosphate concentrations, N/P ratios, and APA values, in representing a P-limitation environment. In addition, the Nearshore Kuroshio Branch Current (NKBC) brings nutrient-enriched subsurface water with low N/P ratios up onto the ECS shelf even approaching the CJ estuary in summer (Yang et al., 2012, 2013). NKBC intrusion may compensate the excess $\mathrm{N}$ in the plume region and further complicate the unbalanced nutrient status of the CJ plume system. In this study, we presented 3-D structures of hydrographic parameters, nutrients, $\mathrm{Chl} a$, and applied APA assays to probe whether phytoplankton physiologically endured $\mathrm{P}$ stress in such a N-replete and hydrographically complicated CJ plume region. A conceptual model was constructed and the properness of usage of various P-limitation indicators was discussed from different perspectives.

\section{Materials and methods}

\subsection{Study area and sampling}

Our cruise was conducted during 14-24 August of 2011, just about one week after the invasion of Super-Typhoon Muifa (27 July-9 August; the highest wind speed $\sim 175 \mathrm{~km} \mathrm{~h}^{-1}$; see more details in Hsiao et al., 2013). A total of 28 sampling stations were set in the field of $30-32^{\circ} \mathrm{N}$ and $121-124^{\circ} \mathrm{E}$, where the CJ plume significantly influenced (Fig. 1). Five stations were deployed in the Qiantang (QT) estuary also. Vertical profiles of temperature, salinity, and fluorescence were recorded with a CTD profiler (SBE-9/11 plus, SeaBird) and packaged sensors at a sampling interval of $3 \mathrm{~Hz}$. Water samples were collected starting from $\sim 3 \mathrm{~m}$ deep to the nearbottom layer using a rosette sampler assembled with $10 \mathrm{~L}$ Go-Flo bottles for chemical analyses.

\subsection{Nutrients, total suspended matter, and $\mathrm{Chl} a$ analyses}

Nutrient water samples were filtered through Whatman GF/F filters and analyzed immediately on board for DIN $\left(\mathrm{DIN}=\mathrm{NO}_{3}^{-}+\mathrm{NO}_{2}^{-}+\mathrm{NH}_{4}^{+}\right)$and phosphate following the standard colorimetric protocols (Parsons et al., 1984). The analyses were conducted with a continuous-flow injection autoanalyzer (Technicon AA3-HR; SEAL Analytical). The detection limits for DIN and phosphate with $1 \mathrm{~cm}$ quartz tubes were $0.1 \mu \mathrm{M}$ and $0.05 \mu \mathrm{M}$, respectively. Chl $a$ samples were filtered onto Whatman GF/F filters under pressure $<100 \mathrm{mmHg}$ and then kept in liquid $\mathrm{N}_{2}$ before analysis. In the laboratory, Chl $a$ samples were extracted in the dark at $4{ }^{\circ} \mathrm{C}$ with $100 \%$ acetone for $12-16 \mathrm{~h}$ and then measured with a fluorometer (10-AU; Turner Designs) following the method of Welschmeyer (1994). Total suspended matter (TSM) samples were filtered onto Whatman GF/F filters, folded and wrapped by precombusted aluminum foils after salt washing, and then freeze-dried for $24 \mathrm{~h}$ for weighing in laboratory.

\subsection{Bulk APA}

Samples for bulk APA assays were filtered through a $100 \mu \mathrm{m}$ mesh to remove large zooplankton and then collected with $2 \mathrm{~L}$ acid-cleaned polycarbonate bottles. The zooplanktonfree samples were smoothly preconcentrated onto $0.2 \mu \mathrm{m}$ polycarbonate filters and then resuspended in $50 \mathrm{~mL}$ filtered seawater $(<0.2 \mu \mathrm{m})$ from the same sampling depth. APA was measured using a sensitive fluorometric protocol similar to Perry (1972) with 3-o-methylfluorescein phosphate substrate (3-o-MFP; Sigma). For each sample, $6 \mathrm{~mL}$ triplicate sample waters and $0.75 \mathrm{~mL} \mathrm{3-o-MFP} \mathrm{substrate} \mathrm{were} \mathrm{mixed}$ 

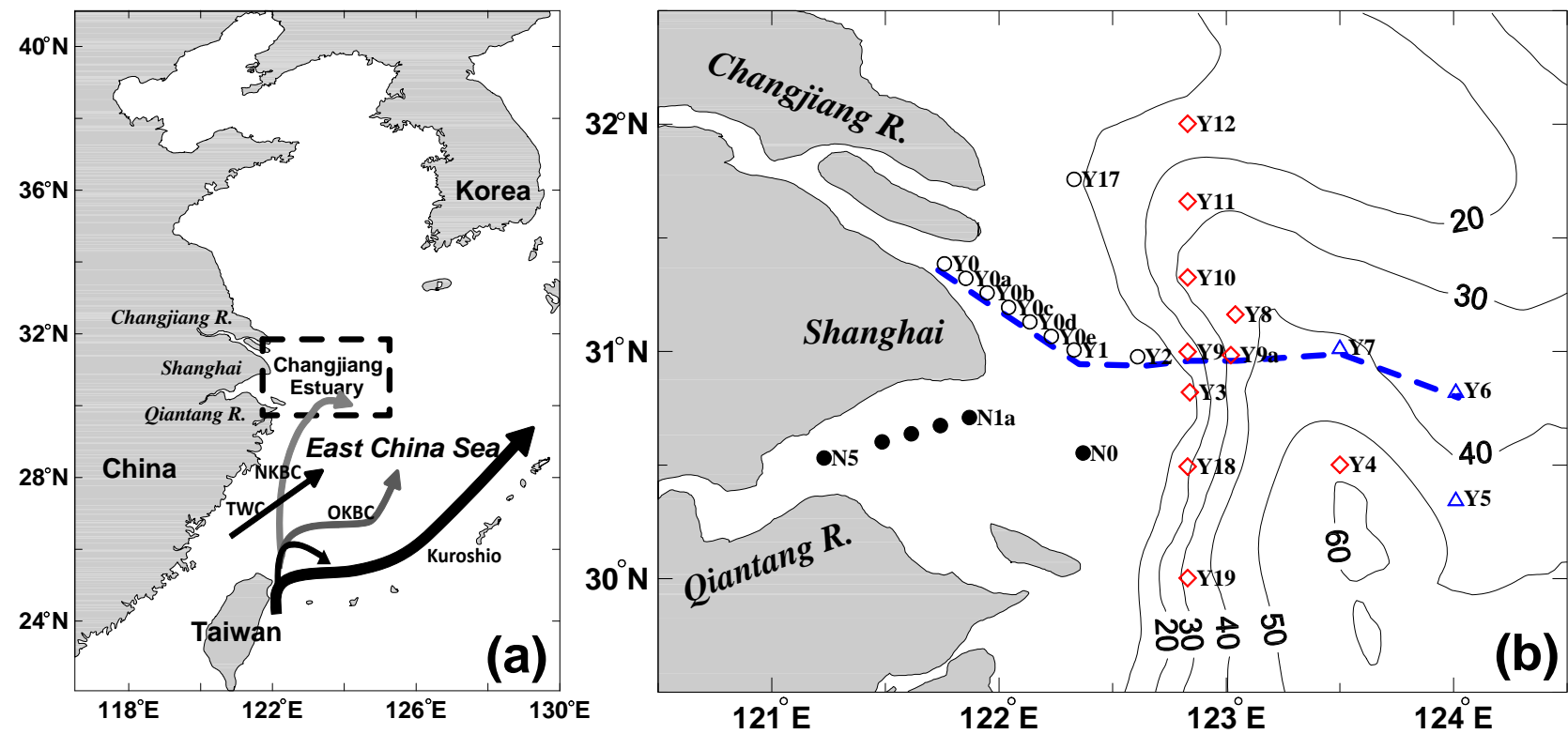

Fig. 1. Location maps of the Changjiang estuary and the East China Sea (a) and sampling stations with bathymetry (m, solid curves) off the Changjiang River mouth (b). The stations influenced by turbidity are represented by open circles. Red diamonds and blue triangles represent upwelling-influenced and plume fringe stations, respectively. The CJ transect (dashed line) comprises estuary stations from Y0 through Y1, then Y2, Y9, Y9a, Y7, and Y6.

in a $10 \mathrm{~mL}$ glass tube to yield a final substrate concentration of $\sim 250 \mathrm{pmol} \mathrm{mL}^{-1}$. Then samples were incubated in the dark at $25^{\circ} \mathrm{C}$ for $4 \mathrm{~h}$. We used a fluorometer (TD-700; Turner Designs) equipped with a set of filters (excitation wavelength $=475 \mathrm{~nm}$; emission wavelength $=515 \mathrm{~nm}$ ) to determine 3-o-MF concentrations initially and after $4 \mathrm{~h}$ incubation.

\section{Results}

\subsection{Spatial distribution patterns of measured parameters in the surface $\mathbf{C J}$ plume}

Surface temperature $\left(23.9-29.5^{\circ} \mathrm{C}\right)$ decreased eastward basically with the highest value in the river mouth (Fig. 2a). Two cold centers were observed around the stations Y3 and Y12, respectively. Surface salinity (0.3-30.5) showed an eastward increasing pattern with the lowest value in the CJ River mouth (Fig. 2b). Distributions of DIN and phosphate were quite similar (Fig. 2c, d). For DIN, the concentrations descended from $>20 \mu \mathrm{M}$ near the river mouth to $<10 \mu \mathrm{M}$ in the plume fringe with the salinity of $\sim 30$ (Fig. 2b, c). For phosphate, $>2 \mu \mathrm{M}$ concentrations could be seen near the river mouth and then decreased significantly towards the plume fringe to $<0.1 \mu \mathrm{M}$ (Fig. 2d). Surface TSM values ranged from as high as $170-592 \mathrm{mg} \mathrm{L}^{-1}$ near the CJ River mouth, then decreased rapidly, then jumped again at salinity $\sim 17$, and then decreased offshore (Fig. 2e). Surface excess $\mathrm{N}($ excess $\mathrm{N}=[\mathrm{DIN}]-16 \times[$ Phosphate $])$ existed throughout the whole study area with $>100$ values in the CJ estuary and $<10$ values near the plume fringe (Fig. 2f).

For biological parameters Chl $a$ and APA, we observed distinctive patchy distributions (Fig. 2g, h). For Chl $a$ (2.20$24.97 \mathrm{mg} \mathrm{Chl} \mathrm{m}^{-3}$ ), we saw the first bloom patch appeared at the river mouth (station $\mathrm{YOb}$ ) and the second bloom patch appeared in the center (stations Y9 and Y18). The landward boundary of the Chl $a$ patch was found to parallel the turbidity front (red dashed curve in Fig. 2g). The surface distribution of APA differed from those of nutrient and $\mathrm{Chl} a$. Higher APA values were found in the river mouth $\left(9.7 \mathrm{nMh}^{-1}\right.$ at station Y0) as well as in the plume fringe $\left(11.5 \mathrm{nMh}^{-1}\right.$ at station Y7). Note that around the outer plume, the isopleth of $2 \mathrm{nM} \mathrm{h}^{-1}$ of APA was closely related to the isolines of $0.1 \mu \mathrm{M}$ phosphate and $10 \mu \mathrm{M}$ excess $\mathrm{N}$. Note that a clear TSM front was observed in shallow water at around 5-10 m (see bathymetry in Fig. 1b), and then two outcrops of low temperature happened with $\mathrm{N}-\mathrm{S}$ direction along the 20 and $30 \mathrm{~m}$ isobaths with concentrated $\mathrm{Chl} a$ and low APA. This distribution pattern was likely driven by hydrodynamics due to rugged topographic changes underneath.

From nutrient and $\mathrm{Chl} a$ distribution patterns we can see that the QT River mouth is atypical with high nutrients accompanying low Chl $a$ (Fig. 2). The extremely high TSM (1812-2990 $\mathrm{mg} \mathrm{L}^{-1}$ ) appeared in the shallow river mouth of the QT River indicated that a strong resuspension had occurred, while both Chl $a$ and APA remained low. In Sect. 3.3, we will have more discussions on parameters of the QT River 

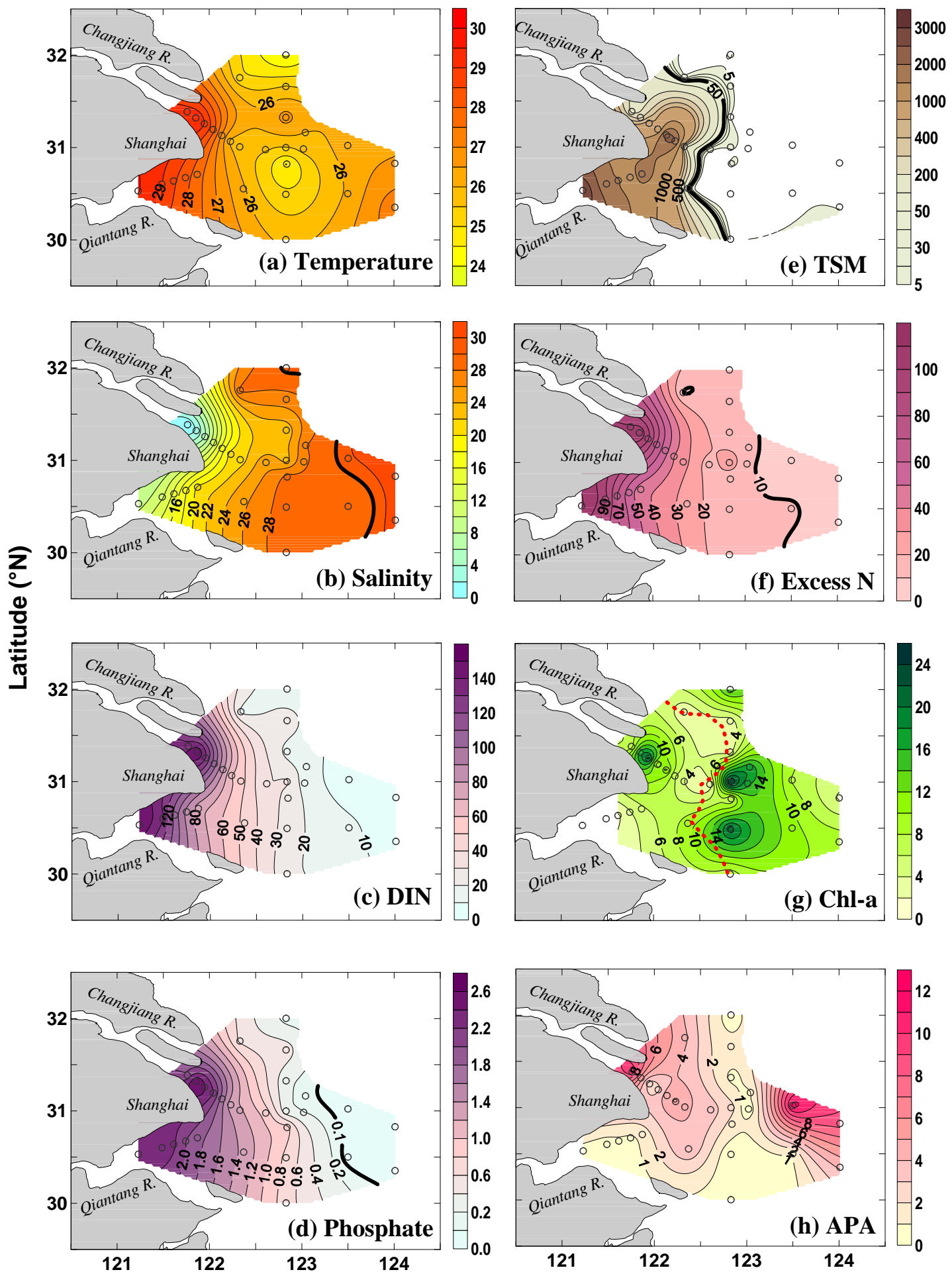

\section{Longitude $\left({ }^{\circ} \mathrm{E}\right)$}

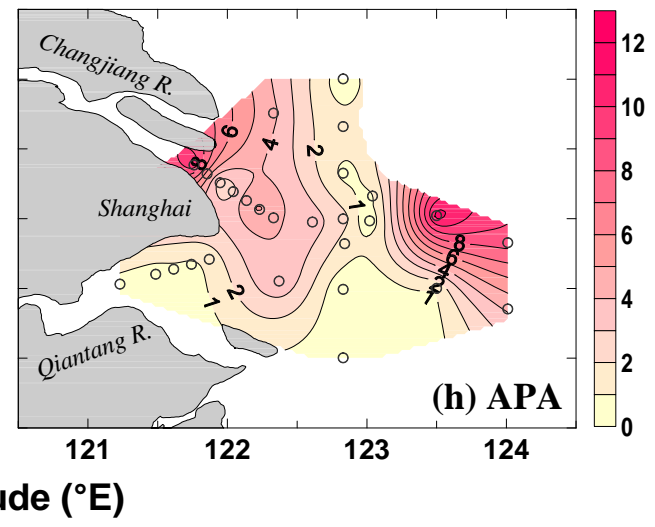

Fig. 2. Spatial distributions of surface $(3 \mathrm{~m})$ parameters of the CJ plume. (a) Temperature $\left({ }^{\circ} \mathrm{C}\right)$, (b) salinity, (c) DIN ( $\left.\mu \mathrm{M}\right)$, (d) phosphate $(\mu \mathrm{M})$, (e) TSM $\left(\mathrm{mg} \mathrm{L}^{-1}\right)$, (f) excess $\mathrm{N}$, (g) Chl $a\left(\mathrm{mg} \mathrm{Chl} \mathrm{m}^{-3}\right)$, and (h) APA $\left(\mathrm{nM} \mathrm{h}^{-1}\right)$. The red dashed curve stands for TSM isoline of $50 \mathrm{mg} \mathrm{L}^{-1}$. 
versus the entire water body. Below we illustrate the distributions along the offshore plume transect.

\subsection{Offshore transect along CJ plume}

During summer, the Changjiang Diluted Water (CDW) flows predominantly eastward (Lie et al., 2003). Therefore, the CJ transect (see Fig. 1b, stations Y0-Y6) was chosen for illustrating the influence of the CDW on the distributions of environmental parameters. High-temperature and low-salinity water was restricted in the river mouth (Fig. 3a, b). From the salinity pattern, we saw a clear wedge-like plume dispersing outward. The stratification was created by the density difference when the bottom depth went deeper than $20 \mathrm{~m}$. A feature of upwelling intrusion, as mentioned earlier caused by th NKBC, could be judged by the bulged thermocline around stations $\mathrm{Y} 9$ and $\mathrm{Y} 9 \mathrm{a}$ where topographic change was significant (Fig. 3a). DIN showed a vertically well-mixed pattern in the nearshore shallow water, yet a significant vertical difference with lower DIN in surface and higher DIN in deep could be observed at the plume fringe (Fig. 3c). Phosphate concentrations were observed $>0.2 \mu \mathrm{M}$ throughout the entire section except the surface of the outer plume (Fig. 3d). Interestingly, phosphate pattern resembling that of temperature showed an intrusion-like pattern but outcropped between the stations $\mathrm{Y} 2$ and $\mathrm{Y} 9$.

TSM in freshwater end was $170-261 \mathrm{mg} \mathrm{L}^{-1}$, but it increased dramatically to $>2000 \mathrm{mg} \mathrm{L}^{-1}$ within $45 \mathrm{~km}$. This turbidity maximum occurred at the salinity around 15-20 near stations YOd and Y0e (Fig. 3e). Note that TSM concentrations dropped to $<10 \mathrm{mg} \mathrm{L}^{-1}$ between the stations $\mathrm{Y} 2$ and Y9 where low-temperature water came up from the subsurface. Excess $\mathrm{N}$ existed throughout the entire transect except the bottom of the outer plume (stations Y6 and Y7; Fig. 3f). Zero excess $\mathrm{N}$ indicated an external supply of phosphate from the bottom to compensate the imbalanced nutrient ratios of this plume system. Two clear Chl $a$ blooms developed, one at the river mouth stations ( $\mathrm{YOa}$ and $\mathrm{YOb}$ ) and the other near the surface of upwelling outcrops (Y2 through Y9a). The latter one held concentrations more than $16 \mathrm{mg} \mathrm{Chl} \mathrm{m}^{-3}$ in the patch centers (Fig. 3g). APA also showed patchy distribution; however, locations of APA patches were inconsistent with those of Chl $a$ (Fig. 3g, h). High APA values emerged in the river mouth (station Y0) and the surface of the plume fringe (stations Y6 and Y7). Note that high surface APA in the plume fringe coexisted with low phosphate concentrations, while excess $\mathrm{N}$ was still high (Fig. 3d, f, h).

\subsection{Parameters along the salinity gradient}

In this section, we illustrate TSM, DIN, phosphate, N/P ratio, Chl $a$, and APA distributions along the salinity gradient over the entire water body we monitored. In Fig. 4a, we can see high TSM, so-called turbidity maximum, at moderate salinity. The high-TSM zone of the QT estuary distributes in a wider salinity range (5-21) comparing with that of the CJ estuary (17-21). However, a sharp TSM front appears at the salinity of $\sim 21$. In Fig. $4 \mathrm{~b}$ and c, DIN and phosphate basically display linear decreasing trends when salinity ranges from 0 to 20 , indicating that conservative mixing predominates the nutrient status at low-salinity side. However, the trend of the QT estuary is above that of the CJ estuary at the given salinity. We suggest that such a high nutrient trend in the funnel-shaped QT estuary may be caused by procrastinated water exchange due to strong tidal effects and/or prohibited biological consumption by phytoplankton due to high water turbidity. When the salinity is greater than 21 , scattered data points with significant drawdown of DIN and phosphate can be seen. The phosphate uptake is apparent, yet high phosphate values can be seen at the salinity of 34.5 occupied by P-replete bottom water.

In Fig. 4d, we can see N/P ratios decrease continuously as salinity increases. Theoretically, if the plume mixes with nutrient-free water during plume dispersing outward, the ratios would not be salinity dependent. However, the N/P ratios descend from 70 at freshwater end to $\sim 16$ at the salinity of $\sim 34.5$. Within the salinity ranges $22-32, \mathrm{~N} / \mathrm{P}$ ratios surge even up to $\sim 200$. In Fig. 4e, we can see QT estuary samples hold significantly lower $\mathrm{Chl} a$ comparing with those of the CJ estuary at given salinity probably due to light inhibition, while for the $\mathrm{CJ}$ estuary samples a sharp increase of $\mathrm{Chl} a$ can be observed within the salinity of $0-5$ where TSM remains at low concentrations. Chl $a$ decreases afterward toward higher salinity of 20-22; meanwhile, TSM reaches its maximum. Note that $\mathrm{Chl} a$ peaks again at salinity of $\sim 22$ to 32 and gradually decreases toward a high-salinity end of 34.5. In Fig. 4f, we can see high APA values at both low- and high-salinity ends. Similar to $\mathrm{Chl} a$, the QT estuary presents lower APA when compared with the the CJ estuary. Interestingly, high APA accompanies low $\mathrm{Chl} a$ at the freshwater end of the CJ estuary. This high APA is apparently allochthonous from the CJ upstream. From salinity of 0 through 5, APA decreases as the increasing of both Chl $a$ and salinity. When salinity is greater than 22, APA occupies a wide range from 0 to $12 \mathrm{nM} \mathrm{h}^{-1}$. Note that APA values surge at the salinity of 22-32 where higher N/P ratios and Chl $a$ occur. At the high salinity side, the low values of $\mathrm{N} / \mathrm{P}$ ratio, $\mathrm{Chl} a$, and APA are from deeper water samples.

\section{Discussion}

\subsection{P-limitation potential from system aspect}

The region we focused on was mainly influenced by the CDW (CDW is defined as the water with salinity $<31$; Gong et al., 1996; Fig. 2b) with high nitrate concentrations and N/P ratios (Shen and Liu, 2009). Excess N was found throughout the entire water column except the bottom of the peripheral plume (Figs. 2f, 3f), implying that $\mathrm{P}$ would 

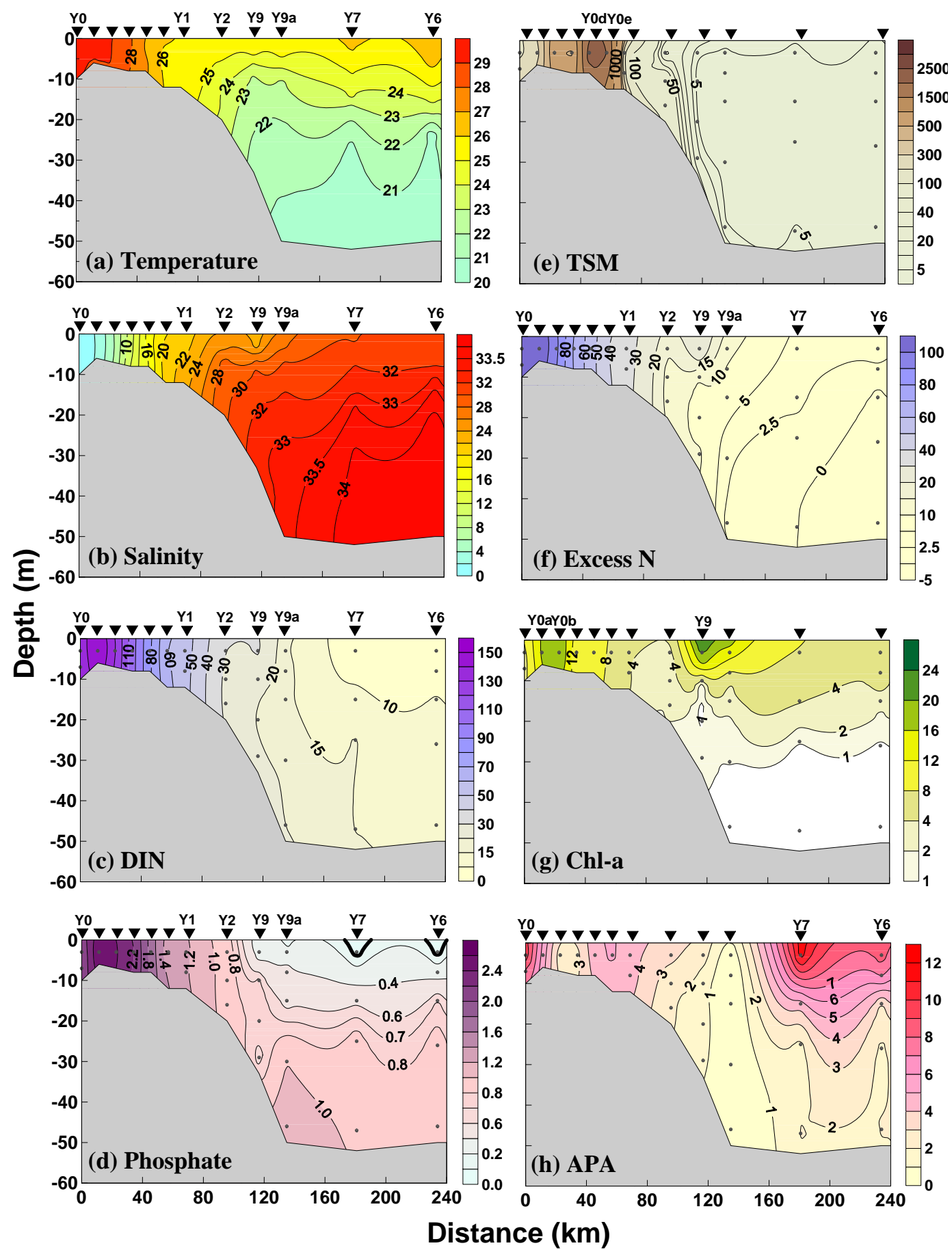

Fig. 3. Vertical distributions of parameters along CJ transect. (a) Water temperature $\left({ }^{\circ} \mathrm{C}\right)$, (b) salinity, $(\mathbf{c})$ DIN $(\mu \mathrm{M})$, $(\mathbf{d})$ phosphate $(\mu \mathrm{M})$, (e) TSM $\left(\mathrm{mg} \mathrm{L}^{-1}\right)$, (f) excess $\mathrm{N}(\mu \mathrm{M})$, (g) Chl $a\left(\mathrm{mg} \mathrm{Chl} \mathrm{m}^{-3}\right)$, and (h) APA $\left(\mathrm{nM} \mathrm{h}^{-1}\right)$. The dots denote the discrete sampling over various depths. The inverted triangles denote the stations.

be used up earlier than $\mathrm{N}$ when the Redfield uptake ratio (Redfield, 1958) is applied for phytoplankton growth. From the system perspective, the entire CDW-influenced shelf areas will endure $\mathrm{P}$ stress ultimately if there is no external $\mathrm{P}$ supply during water dispersion. However, an upwelling caused by topographic uplift near the stations $\mathrm{Y} 9$ and $\mathrm{Y} 9 \mathrm{a}$ (Fig. 3a) and zero excess $\mathrm{N}$ in the bottom of the plume fringe (Fig. 3f) indicated that some extra $\mathrm{P}$ supply to this system occurred. According to temperature $\left(<21^{\circ} \mathrm{C}\right)$ and salinity ( $>34$ ) characteristics in the bottom water of the plume fringe 

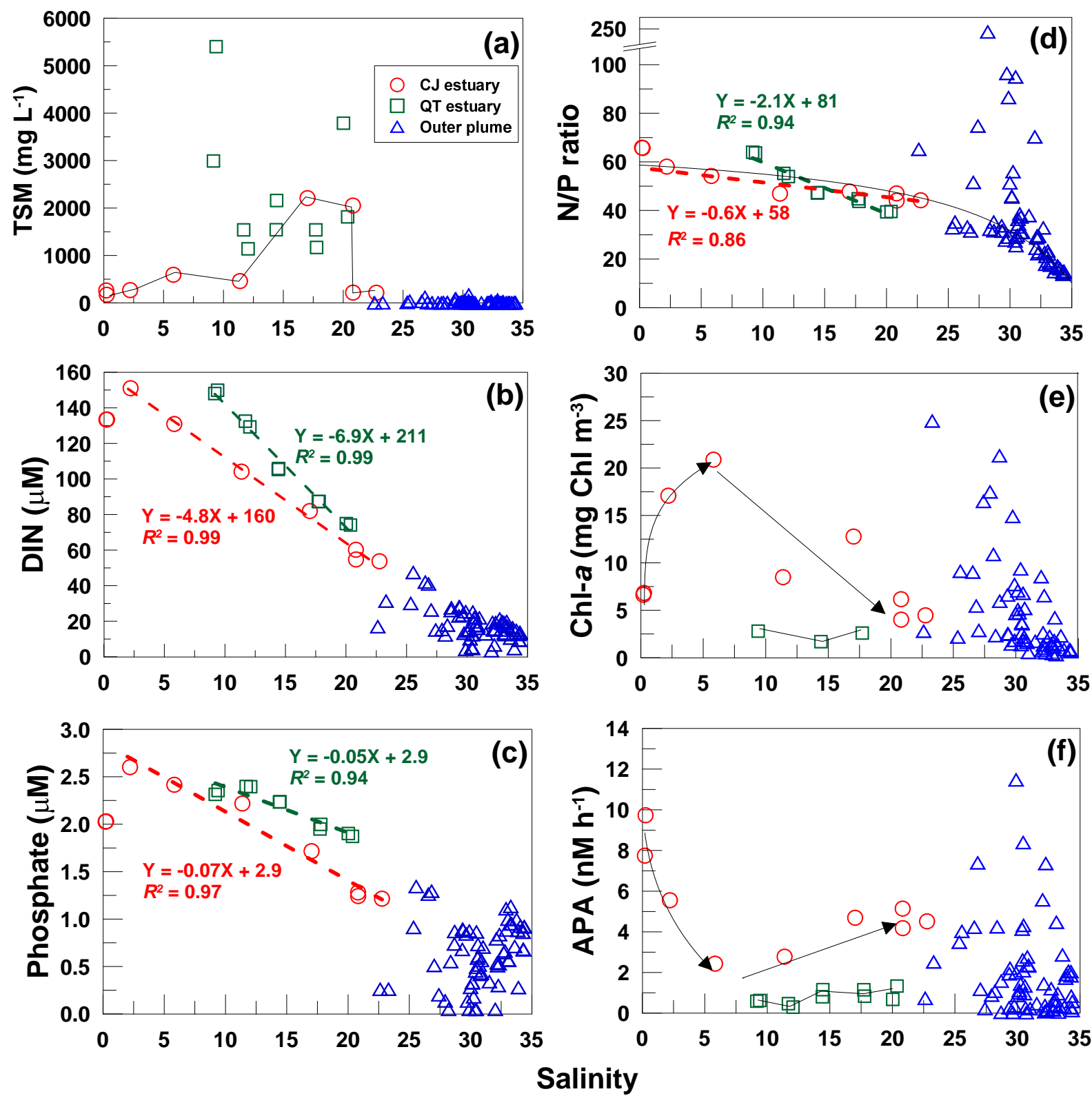

Fig. 4. The variations of TSM (a), DIN (b), phosphate (c), N/P ratio, (d) Chl $a$ (e), and APA (f) in whole water column along estuarine salinity gradient over CJ plume.

(Fig. 3a, b), we suspected that this external P source was from the Kuroshio Intermediate Water, which contains high nutrients but low N/P ratios $(\sim 14)$, that might fuel the primary production of the CJ plume during summer (Zhang et al., 2007).

The intrusion of the Kuroshio Intermediate Water near the CJ plume was first reported by Kondo (1985). Chen (1996) further addressed the significance of this external $\mathrm{P}$ source for ECS productivity. By using the Regional Ocean Modeling System and observational data, Yang et al. (2012) had proved that the bottom-hugging NKBC transported phosphate-rich water from the southern tip of the ECS northward over the shelf to our study area around $30.5^{\circ} \mathrm{N}$ during summer (Fig. 1a). According to the discussion above, such external long-range $\mathrm{P}$ supply from subsurface may make up $\mathrm{P}$ shortage of plume systems. Besides the CJ plume, in northeastern Monterey Bay of the coastal California, Mackey et al. (2012) also reported that the coastal upwelling transported additional phosphate to the surface water and caused 10-fold increase of phosphate concentration to draw down the N/P ratio to $\sim 5$.

In Fig. 5a we plotted DIN against phosphate for all data points, and two significant linear relations with the regression coefficient $R^{2}>0.85$ were obtained. The slopes are as 

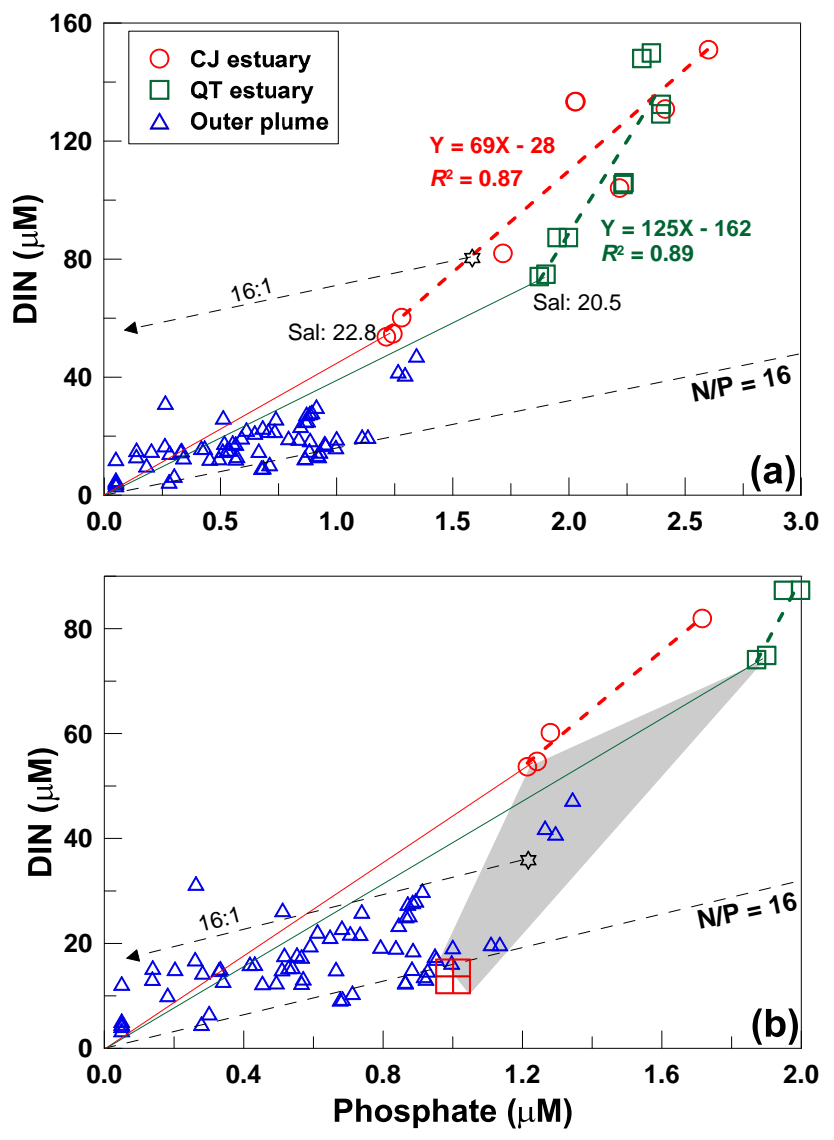

Fig. 5. Correlations between DIN and phosphate in whole water column (a) and low concentration samples (b) of CJ plume.

high as 69 and 125 for CJ and QT estuaries, respectively, and the regression lines both have intercepts at phosphate axis. Meanwhile, we added a line of N/P ratio of 16 for the reference and found many data points in the high-salinity region (salinity of 22-34.5), falling above the reference line following roughly the N/P slope of 16 . Two samples collected at the boundaries of CJ and QT turbidity fronts were taken as the beginning source (see Fig. 5a); then we assumed CDW front waters started to mix with an oligotrophic surface water (zero nutrient) as the plume expanded. Consequently, two conservative mixing lines could be obtained (solid lines in Fig. 5a). If any biological Redfieldian uptake occurred in the water in parallel with the mixing lines (star symbol and 16:1 reference arrow in Fig. 5a), the distributions of observed data points should fall into the left zone of the mixing lines where $\mathrm{N}$ availability (excess $\mathrm{N}$ ) was higher. However, only limited data points fell into the left of the mixing lines, implying that biological uptake indeed happened. These data points surely would create very high N/P ratios. Note that most data points fell into the right zone, indicating an extra contribution from water source with lower $\mathrm{N} / \mathrm{P}$ ratios.

We blew up the distribution field of low-concentration samples (blue triangles in Fig. 5) for discussion. If we mixed the two frontal waters (CJ front and QT front) with a hypothetical source, i.e., the NKBC, we may obtain the gray zone to represent the full field of mixing products from the three endmembers (Fig. 5b). The hypothetical source is supported by Yang et al. (2012), who found the NKBC primarily sourced from 120-250 m of the Kuroshio Intermediate Water, of which the nitrate and phosphate contents were reported to be $11-17 \mu \mathrm{M}$ and $0.7-1.1 \mu \mathrm{M}$, respectively (Chen et al., 1995). Based on this mixed water mass, most of the data points can be explained when the Redfieldian uptake is followed (star and 16:1 reference arrow in Fig. 5b). This estimate confirms the importance of $\mathrm{P}$ supply from subsurface in the $\mathrm{CJ}$ plume region.

As we mentioned in the Introduction, the $\mathrm{N}$ versus $\mathrm{P}$ fluxes had increased 8 times. Here we attempt to give an estimate for limiting nutrients on the system scale by considering the nutrient inputs from the NKBC and CJ plume. According to Yang et al. $(2012,2013)$, the modeled and observational W-E cross section near the CJ plume revealed a $100 \mathrm{~km}-$ wide, $20 \mathrm{~m}$-thick bottom-hugging current with a northward velocity of $0.5 \mathrm{~m} \mathrm{~s}^{-1}$. This phenomenon gives a NKBC flow of $1 \mathrm{~Sv}\left(Q_{\mathrm{NKBC}}\right)$, which is slightly higher than that $(0.4 \mathrm{~Sv})$ given for the intrusion flow of the Kuroshio Intermediate Water by Chen et al. (1995). In contrast, the peak of CJ discharge $\left(Q_{\mathrm{CJ}}\right)$ was reported to be $50000 \mathrm{~m}^{3} \mathrm{~s}^{-1}(0.05 \mathrm{~Sv})$, which is equal to that applied in the ECS box model by Chen (1996). By utilizing the mean nutrients reported in the 1960s and 2008 and assuming the NKBC persisted at the same magnitude over the past, we estimated the fractional contributions of $\mathrm{N}$ and $\mathrm{P}$ from the $\mathrm{CJ}$ River as well as the $\mathrm{N} / \mathrm{P}$ ratios in the 1960s and 2008 (Table 1). The estimated fractional contribution of $\mathrm{N}$ from CJ discharge increased from 8-19\% to $36-58 \%$ in the past 4 decades. Similarly, P contribution from CJ discharge increased from $1-4 \%$ to $11-24 \%$. Obviously, the nutrient entry from $\mathrm{CJ}$ discharge had increased significantly and the imbalance of dissolved N/P ratios had developed gravely in the CJ plume. This estimate is rough, however, telling us that the CJ plume ecosystem has a tendency toward $\mathrm{P}$ limitation, and it seems that we have passed the threshold of $16(\mathrm{~N} / \mathrm{P}=19-25$ at present day, Table 1).

Standing on this point, we recognize that understandings about water exchange and input-output budget of nutrients in the entire summer plume system are crucial since the supply and the relative contribution of $\mathrm{N}$ and $\mathrm{P}$ from the CJ River and NKBC are changing seasonally and interannually, and thus the nutrient status and stoichiometry. Therefore, we can hardly say the CJ plume system was P-limited even when the excess-N phenomenon was significant during our summer cruise. In addition, evidence of high APA on the surface near the plume fringe may only tell us that $\mathrm{P}$ limitation had occurred at that specific site where $\mathrm{P}$ consumption rate was greater than $\mathrm{P}$ supply rate at that specific time period (see Fig. 8, conceptual model). However, Chen et al. (2001) found that $\mathrm{N}$ instead of $\mathrm{P}$ in summer limited the phytoplankton growth over the entire ECS where the surface salinity 
$>32$. Their nutrient addition bioassay experiments further supported the importance of the NKBC in P supply in terms of system perspective.

\subsection{Joint effect of CDW and coastal upwelling on phytoplankton $\mathbf{P}$ stress in $\mathrm{CJ}$ plume}

P limitation of phytoplankton has been observed in other overexploited coastal ecosystems. For example, Fisher et al. (1992) reported that during high runoff periods in spring and autumn, the Chesapeake Bay was limited by phosphate with the observation of high N/P ratios, high APA, and short $\mathrm{P}$ turnover time. Phytoplankton growth in the surface water of the Mediterranean Sea during the stratified summer season was also limited by P availability (Vaulot et al., 1996). Sylvan et al. (2006) found that excess N loading to the Mississippi River watershed had periodically enhanced the $\mathrm{P}$ limitation in the downstream Louisiana shelf. However, the aforementioned studies applied bioassays and APA rather than solely depended on N/P ratios or absolute concentrations. Previous studies had indicated that nutrient standing stock should not be taken as a reliable indicator of nutrient limitation/availability (Turner and Rabalais, 2013).

In this study, the phenomenon of significant excess $\mathrm{N}$, detectable P, and APA were observed throughout the water column. Their spatial patterns against the salinity gradient were either coupled or decoupled with Chl $a$. The complicated distributions seemed to be attributed to hydrodynamically associated processes, such as freshwater plume with allochthonous input, TSM resuspension, and coastal upwelling. Below we try to disentangle the complex correlations between parameters associated with phytoplankton growth (Fig. 4). Note that low Chl $a$ was observed in the QT estuary with extremely high TSM (Fig. 2e, g), implying phytoplankton growth might be completely inhibited in the QT estuary. Therefore, only the CJ transect was used for discussion.

For the inner estuary, APA decreased as salinity increased (Fig. 4f), indicating the dilution of allochthonous APA had occurred. Meanwhile, increase of $\mathrm{Chl} a$ concentrations could be observed (Fig. 4e). Under such a condition of high nutrient availability, the inverse relation between APA and Chl $a$ indicates that phytoplankton growth might not suffer from P limitation. We suggest that the highly allochthonous APA is likely sourced from limnetic heterotrophic bacteria (Cao et al., 2010). Studies had confirmed that bacteria would excrete $\mathrm{AP}$ to utilize $\mathrm{C}$ from DOM in nutrient-replete but lightlimited environments in order to satisfy their $\mathrm{C}$ demand instead of P demand (Van Wambeke et al., 2002).

As the plume kept dispersing seaward, Chl $a$ was dropped down gradually as TSM jumped up (Fig. 4a, e), underlining the importance of light availability to phytoplankton growth. In highly anthropogenically influenced coastal ecosystems, turbidity is one of the major factors restricting phytoplankton growth by reducing light transmission in the water column
(Pei et al., 2009). Therefore, phytoplankton do not bloom in turbid coastal waters where nutrients are abundant. Our observation showed that the Chl $a$ patch just attached to the turbidity front (red dashed curve; Fig. 2g), providing strong support that light could restrict the bloom development near CJ coastal stations. The result is consistent with the previous study of light limitation in turbid estuaries (Cloern, 1999). Contrary to Chl $a$, APA values increased seaward and remained fairly high compared with those in the outer plume (Fig. 4f). Such high APA in turbidity maximum zone was also likely sourced from heterotrophic bacteria. This nonphytoplankton-induced APA would subsequently cause high Chl- $a$-normalized APA ( $\left.\mathrm{APA}_{\mathrm{Chl}}\right)$ in the CJ estuary under high phosphate status.

As mentioned earlier, when salinity $>21$ the water contained less TSM; then Chl $a$ and APA started to build up (Fig. 4a, e, f). Below, we discuss the vertical distributions of phosphate and biological parameters in the CJ transect (Fig. 6). Meanwhile, we use APA $\mathrm{Chl}_{\mathrm{l}}$ for representing the $\mathrm{P}$ stress on the cell physiological level. Note that due to the shallow depth in the inner estuary of the CJ transect, we only sampled one single depth from Y0 to Y1, thus not allowing us to discuss the depth profiles.

From the vertical structures in Fig. 6, we see low Chl $a$ but high phosphate for station Y2 throughout the water column, yet APA is above $2 \mathrm{nMh}^{-1}$. This APA we believe is partly from allochthonous APA and partly from autochthonous bacteria since the station is just located at the TSM front (Fig. 2e). Nevertheless, phytoplankton may have some contribution to APA in surface samples according to the higher $\mathrm{Chl} a$ concentrations observed. However, it is difficult for us now to separate the contribution of APA from phytoplankton. As for stations $\mathrm{Y} 9$ and $\mathrm{Y} 9 \mathrm{a}$, water column APA decreases seaward. Likely, the effect of allochthonous APA still remains at station Y9. However, APA is almost non-detectable at station Y9a throughout the water column. The blank APA zone can be seen in Fig. 3h also. In contrast to APA, Chl $a$ is very high on the surface and it decreases rapidly as the water depth increases, reasonably controlled by light availability. Moreover, phytoplankton activity is going deeper at station Y9a (judging by Chl $a$ concentrations), being farther away from the turbidity front. Interestingly, at the surface water of these two stations with very high phytoplankton activity, phosphate concentrations are both around $\sim 0.2 \mu \mathrm{M}$, which already reaches the P-limitation criterion of $0.2 \mu \mathrm{M}$ (Dortch and Whitledge, 1992). However, the bloom is unlikely P-limited according to low APA. Such high Chl $a$ coexisting with low phosphate concentrations (also seen in Fig. 3d, g) indicates that phytoplankton would rapidly consume phosphate during the bloom formation (Arrigo, 2005). This fast nutrient consumption would cause high N/P ratios on the surface (70-125; Fig. 4d). Unfortunately, there are limited articles describing the $\mathrm{N} / \mathrm{P}$ ratios of $\mathrm{POM}$ in this area (PON/POP = 3.3-18; Yu et al., 2012). 
Table 1. Estimation of the fractional contributions of N and P from the Changjiang River in the 1960s and 2008.

\begin{tabular}{|c|c|c|c|c|c|c|c|c|c|}
\hline \multirow[t]{2}{*}{ Year } & $Q_{\mathrm{CJ}}$ & $2_{\mathrm{NKBC}}$ & $\mathrm{N}_{\mathrm{CJ}}$ & $\mathrm{N}_{\mathrm{NKBC}}$ & $\mathrm{P}_{\mathrm{CJ}}$ & $\mathrm{P}_{\mathrm{NKBC}}$ & \multirow[t]{2}{*}{$\mathrm{N} / \mathrm{P}$} & \multicolumn{2}{|c|}{ CJ contribution } \\
\hline & \multicolumn{2}{|c|}{$(\mathrm{Sv})$} & \multicolumn{4}{|c|}{$(\mu \mathrm{M})$} & & $\% \mathrm{~N}$ & $\% \mathrm{P}$ \\
\hline $1960 \mathrm{~s}$ & 0.05 & 0.4 & 25 & 13.5 & 0.3 & 1 & 16 & 19 & 4 \\
\hline $1960 \mathrm{~s}$ & 0.05 & 1.0 & 25 & 13.5 & 0.3 & 1 & 15 & 8 & 1 \\
\hline 2008 & 0.05 & 0.4 & 150 & 13.5 & 2.5 & 1 & 25 & 58 & 24 \\
\hline 2008 & 0.05 & 1.0 & 150 & 13.5 & 2.5 & 1 & 19 & 36 & 11 \\
\hline
\end{tabular}

Note: $Q_{\mathrm{CJ}}$, runoff of Changjiang (CJ); $Q_{\mathrm{NKBC}}$, transport of the Nearshore Kuroshio Branch Current (NKBC); $\mathrm{N}_{\mathrm{CJ}}, \mathrm{DIN}$ for $\mathrm{CJ} ; \mathrm{N}_{\mathrm{NKBC}}$, DIN for NKBC; $\mathrm{P}_{\mathrm{CJ}}$, phosphate for $\mathrm{CJ} ; \mathrm{P}_{\mathrm{NKBC}}$, phosphate for NKBC.
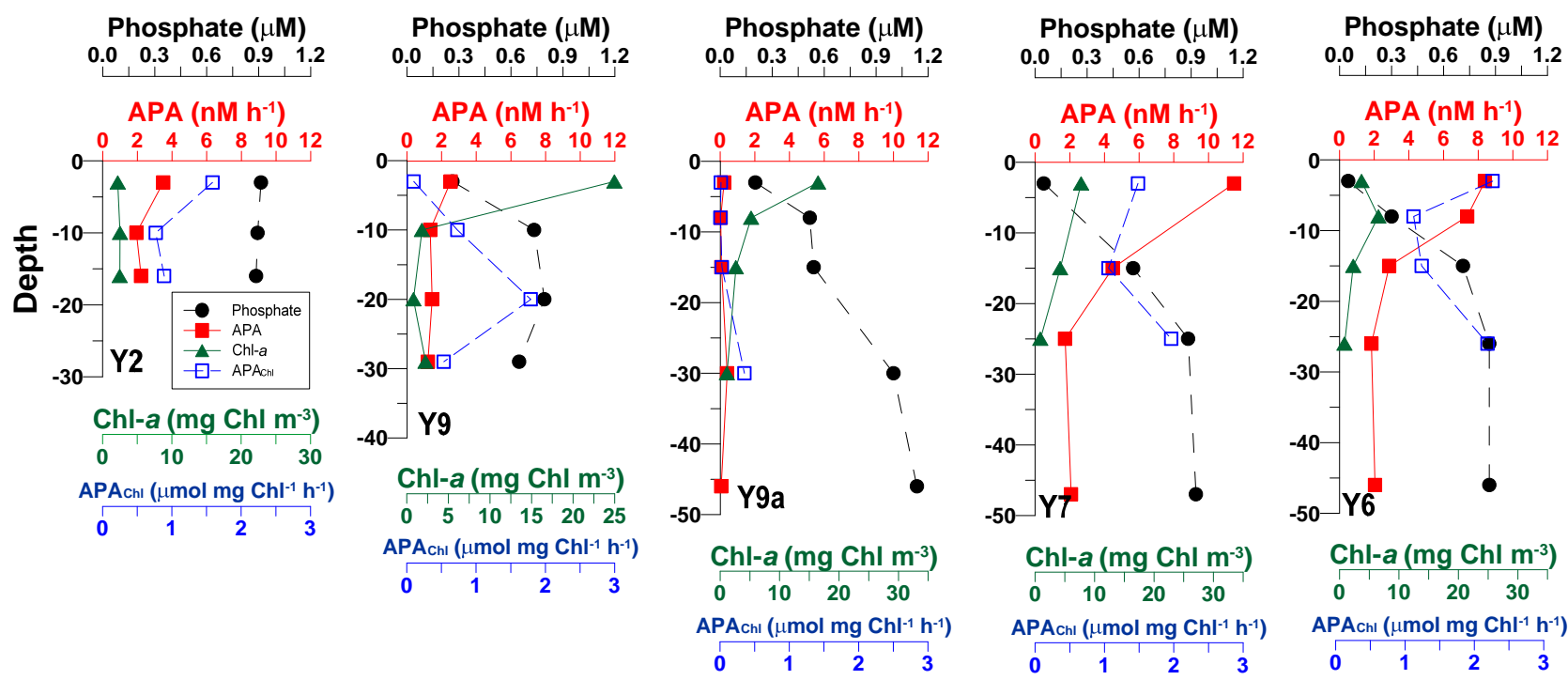

Fig. 6. Vertical profiles of phosphate, APA, Chl $a$, and $\mathrm{APA}_{\mathrm{Chl}}$ for stations along the $\mathrm{CJ}$ transect off the turbidity front.

For stations $\mathrm{Y} 7$ and $\mathrm{Y} 6, \mathrm{Chl} a$ is high on the surface but not as high as on the surfaces of stations $\mathrm{Y} 9$ and $\mathrm{Y} 9 \mathrm{a}$, and phytoplankton activities go deeper compared with station Y9a according to Chl $a$ concentrations (Fig. 6). Meanwhile, APA on the surfaces of stations $\mathrm{Y} 7$ and $\mathrm{Y} 6$ is much higher than that on the surfaces of stations Y9 and Y9a. In contrast, phosphate concentrations are lower than $0.1 \mu \mathrm{M}$ on the surfaces of stations Y7 and Y6 where clear downward decreasing patterns of APA are observed. Phosphate profiles' mirror image with APA profiles also illustrates the importance of phosphate supply from the subsurface. Comparing with station Y9a, APA of deeper-water samples is higher at these two plume fringe stations. We observed subsurface nitrite and ammonium maximums at around $20 \mathrm{~m}$ deep (Hsiao et al., 2013), implying more intensified biological activities had occurred in the subsurface layer. Therefore, we hypothesize that APA in deepwater samples is induced by bacteria relying on sinking particles from the surface.

Based on above discussions, we conclude that $\mathrm{APA}_{\mathrm{Chl}}$ in coastal zones can be altered by allochthonous APA, while in upwelling zones $\mathrm{P}$ supply may compromise $\mathrm{P}$ consumption to maintain the bloom, even though the standing stock of phosphate stays low. In the plume fringe, APA may be enhanced by limited phosphate supply due to stratification. Such deficient phosphate can induce phytoplankton to produce AP for obtaining additional $\mathrm{P}$ from DOP to sustain their growth. Therefore, excess $\mathrm{N}$ coupled with low phosphate concentrations, high N/P ratios, and high $\mathrm{APA}_{\mathrm{Chl}}$ provided here makes a strong case for $\mathrm{P}$ stress in the $\mathrm{CJ}$ plume fringe.

In fact, phytoplankton bloom contributed by harmful algae has been frequently recorded near stations $\mathrm{Y} 9$ and $\mathrm{Y} 9 \mathrm{a}$ since 2000 (Shen et al., 2011; Liu et al., 2013). The enhanced nutrient concentrations caused by increasing anthropogenic activities had stimulated red tide outbreaks around the plume front (Chai et al., 2006; Wang, 2006; Zhou et al., 2008) where both light and nutrient were sufficient for algae growth. At stations Y9 and Y9a, TSM concentrations decreased dramatically (Fig. 3e) while nutrient concentrations still remained (Fig. 3c, d), forming an ideal condition for phytoplankton growth. In addition, the hydrodynamic convergence around the plume front might facilitate the algae aggregation (Tang et al., 2006; Zhou, 2010). Around the CJ plume, Prorocentrum donghaiense, Skeletonema costatum, 
Prorocentrum dentatum, and Noctiluca scintillan were observed as the major red tide species (Liu et al., 2013). Among these species, $P$. donghaiense, holding high affinity with DOP, could adapt well to P-limited conditions (Ou et al., 2008). Huang et al. (2005) had confirmed that $P$. donghaiense could utilize DOP by producing AP to sustain their growth. Therefore, $P$. donghaiense was predominant in offshore $\mathrm{P}$ limited stations (Liu et al., 2013). In our study, we observed high APA in phosphate-depleted surface water of the plume fringe (Fig. 2d, h). Although we do not have DOP measurements, previous study indicated that DOP concentrations was sufficient at the plume fringe $(0.15-0.25 \mu \mathrm{M}$; Hung et al., 2003).

\subsection{Applicability of P-deficient indicators in CJ plume}

Phosphate concentrations, $\mathrm{N} / \mathrm{P}$ ratios, and $\mathrm{APA}_{\mathrm{Chl}}$ are broadly used for describing the P deficiency of phytoplankton (Krom, 1991; Dyhrman et al., 2006, Mather et al., 2008; Duhamel et al., 2010). Thus, the applicability of these parameters as P-deficient indicators are discussed by using Fig. 7, in which only surface data are applied. In addition, the stations are classified into three categories - turbidityinfluenced, upwelling-influenced, and plume fringe regions (Fig. 1) - based on physical and geographical features mentioned before for further comparison. The stations shallower than $10 \mathrm{~m}$ with visible TSM are classified as the turbidityinfluenced region. According to the temperature variation, we recognize that the upwelling outcrops at the seaward side of the turbidity front due to geographically dramatic changes. Thus the stations located on the sharp geophysical uplift are classified as the upwelling-influenced region. Other stations with surface salinity higher than 29.5 are classified as the plume fringe region.

Theoretically, APA is produced while phosphate concentration is depleted; thus an inverse expression of APA and phosphate concentration is expected (Hoppe, 2003). In our case, apparently, the CJ discharges vast amounts of phosphate and allochthonous APA to alter this correlation (open circles in Fig. 7a). Moreover, upwelled phosphate through rapid consumption might inhibit APA formation even in the condition of phosphate $<0.2 \mu \mathrm{M}$, the criterion suggested by Dortch and Whitledge (1992). Hu et al. (1989) specified that plankton growth is P-limited when ambient $\mathrm{N} / \mathrm{P}$ ratios are higher than 30 (reference vertical line in Fig. 7b) based on in situ enrichment experiments. If the ratio is applicable, we should observe a positive correlation between APA and N/P ratio. However, APA results seem to refute the appropriateness of $\mathrm{N} / \mathrm{P}$ ratio as a P-limitation indicator since low APA values correspond to high N/P ratios (20-120) caused by upwelling (Fig. 7b). The inverted phenomenon (high N/P ratios accompany with low APA) in the upwelling region might be explained by strong phosphate utilization of phytoplankton during blooming period (Arrigo, 2005). Even a pseudopositive relation is seen for turbidity-influenced samples, we clearly know this relation is caused by allochthonous APA input. In the past, most researchers used N / P ratio to circumscribe the chemically defined space for $\mathrm{P}$ limitation of phytoplankton in the CJ estuary and ECS. Therefore, one should be careful to only use $\mathrm{N} / \mathrm{P}$ ratio for identifying the nutrient status in the CJ estuary.

On the other hand, an inverse expression of $\mathrm{APA}_{\mathrm{Chl}}$ and phosphate concentrations is expected (Perry, 1972; Dyhrman and Ruttenberg; 2006). In our study, however, such negative correlation is basically observed in turbidity-influenced samples (Fig. 7c). $\mathrm{APA}_{\mathrm{Chl}}$ and phosphate concentrations are out of synchronization in the upwelling region since the supply and biological consumption of phosphate might be equally fast. Therefore, even $\mathrm{APA}_{\mathrm{Chl}}$ would not be a reliable indicator for tracing $\mathrm{P}$ stress of phytoplankton in dynamic water. Similarly, no correlation can be found between $\mathrm{APA}_{\mathrm{Chl}}$ and $\mathrm{N} / \mathrm{P}$ ratio (Fig. 7d). To date, all chemical and physiological indicators have been evident to be improper in the system affected jointly by freshwater plume and upwelling. Raymont (1980) proposed that the presence of remaining nitrate together with undetectable phosphate within the euphotic zone can be used as a major line of evidence for P limitation in marine waters. In this study, only two among the three stations in the plume fringe offer credible evidence for P limitation. Moreover, this evidence happens only in the surface water.

\subsection{Conceptual model for CJ plume}

According to the interpretation of field data, we propose a conceptual scheme of phytoplankton growth dynamics under the joint effect of CDW and coastal upwelling over the CJ plume (Fig. 8). At the river mouth end, surface turbidity is not high and thus surface phytoplankton growth is substantially independent of light confinement. In this area some phosphate is even released into the water from sediment resuspension, and APA is majorly transported by the river-side source. The APA may be mainly produced by bacteria and independent of phosphate regulation. When the river water is dispersed seaward, the plume encounters energy from the ocean and TSM reaches the maximum. In such a turbid area, light is the primary limiting factor controlling phytoplankton growth, and the slightly increased APA is likely released from suspended particles. At the junction front of the CDW and seawater, a sudden drop in topography allows the reduction of turbidity; meanwhile, the upwelling outcrops. In this transition zone, the CDW and upwelled NKBC codominate the nutrient status. Thus phytoplankton in the upwelling zone are frequently immersed in additional phosphate supply from subsurface for relieving P deficiency and sustaining the bloom. In addition, simultaneously strong biological activities accelerate the utilization of phosphate and promote the $\mathrm{N} / \mathrm{P}$ ratio up to an extremely high value. In the plume fringe, strong stratification inhibits the upward transportation of nutrients. Meanwhile, biological activities continuously consume the available phosphate, leading to serious 

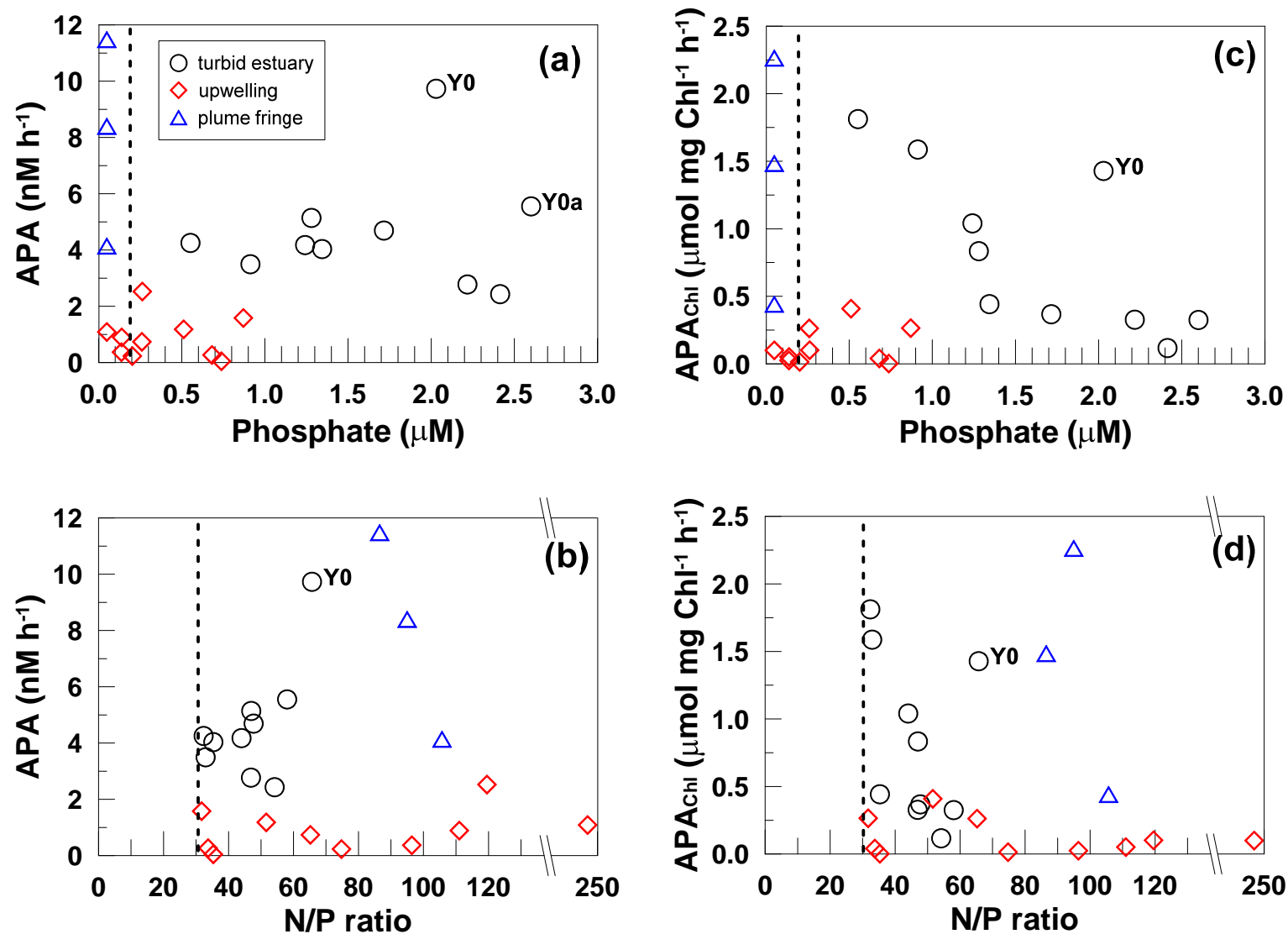

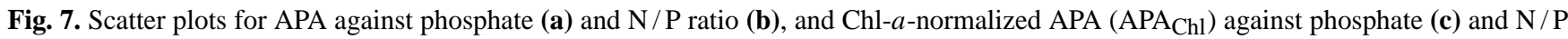
ratio (d) for surface samples except the Qiantang estuary. The stations influenced by turbidity are represented by open circles. Red diamonds and blue triangles represent upwelling-influenced and plume fringe stations, respectively.

P limitation. In such a P-deficient area, phytoplankton will turn to utilize ambient DOP by increasing APA to overcome the $\mathrm{P}$ deficiency. In addition, dead phytoplankton are decomposed via zooplankton grazing and bacterial remineralization, producing abundant nitrite and ammonia accumulated in the subsurface (Hsiao et al., 2013).

Harrison et al. (2008) had proposed a conceptual diagram of phytoplankton growth in the Pearl River estuary. He pointed out that, during the intensive phytoplankton growth period, the running-out of phosphate and the remaining nitrogen may potentially enhance P limitation. Physiologically, phytoplankton are not $\mathrm{P}$-deficient during the blooming period when $\mathrm{APA}_{\mathrm{Chl}}$ is low. The $\mathrm{P}$ stress occurs mainly during the late stage of blooming. However, in our case, we found that algal bloom appeared in contact with the turbidity front and the lasting of algal bloom was mainly due to the rich phosphate supply from the upwelling induced by the NKBC. We suggest that in the CJ plume case the scale of Chl $a$ bloom and phytoplankton $\mathrm{P}$ deficiency are closely associated with the upwelling intensity, which might be controlled by the size of the CDW (Chen, 2000).
Besides the nutrient-replete CJ plume, in the ECS Liu et al. $(2010,2013)$ explored the P stress of microphytoplankton by using APA and the maximum quantum efficiency of photosynthesis (Fv/Fm) assay. Similarly, the expression of APA was blocked on the surface of the upwelling region, and high APA was recorded on the surface of the CJ plume fringe. Both studies agree well that physical processes, such as river plume and coastal upwelling, play major roles in regulating phytoplankton P status and thus APA expression. Note that the values of $\mathrm{APA}_{\mathrm{Chl}}$ in our study are much lower than those reported in the ECS due to methodology. In our study, we analyzed the bulk APA by concentrating the water sample directly, while their analysis in the ECS was majorly for microphytoplankton collected by phytoplankton net. More studies are required to discern the major contributors to APA and $\mathrm{Chl} a$ for exploring phytoplankton-driven $\mathrm{P}$ dynamics.

\section{Conclusions}

Combining 3-D structures of nutrient concentrations and ratios, Chl $a$, and APA parameters, our results indicate that phytoplankton growth in the $\mathrm{CJ}$ plume with excessive $\mathrm{N}$ is 


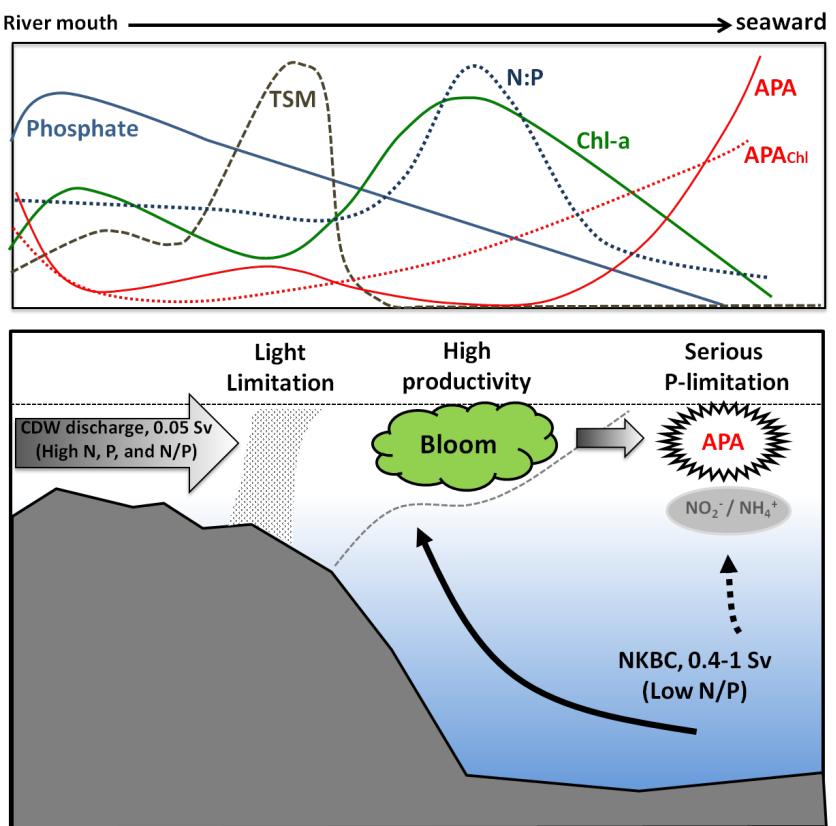

Fig. 8. Conceptual diagram for the interaction between the Changjiang Diluted Water (CDW) and coastal upwelling NKBC on algal bloom and $\mathrm{P}$ limitation of $\mathrm{CJ}$ plume. The offshore variations of the associated parameters are shown on the top.

basically controlled by light availability and P supply. However, the coastal upwelling from the NKBC is an important phosphate source to phytoplankton of the CJ plume. A conceptual scheme of nutrient, $\mathrm{Chl} a$, and APA dynamics under the joint effect of CDW and coastal upwelling over the CJ plume was constructed. Allochthonous APA and upwelled $\mathrm{P}$ strongly influence the applicability of APA and $\mathrm{APA}_{\mathrm{Chl}}$ as physiological P-stress indicators. Neither phosphate concentration nor N/P ratio is proper as a chemically defined $\mathrm{P}$-stress indicator also. Only limited surface area in the CJ plume fringe with excess $\mathrm{N}$ suffered from $\mathrm{P}$ limitation, where diapycnal P supply was prohibited and phytoplankton growth was low. The question of "P limitation" turns out to be a system-dependent question. More qualitative studies, such as the cell-specific APA assay - an enzyme labeled fluorescence (ELF) method - are encouraged to examine the major contributor responsible for APA. We also suggest that the scale of Chl $a$ bloom and phytoplankton P deficiency in the $\mathrm{CJ}$ plume are closely associated with the upwelling strength of the NKBC, which might be regulated by the size of the CDW. Based on our estimation and reasonable assumption, the CJ plume is likely passing over the threshold of $\mathrm{P}$ limitation from the system perspective. If anthropogenic nutrient inputs continually increase, the CJ plume and potentially the ECS shelf will be opposite to other common oceans and become a P limitation in the future.
Acknowledgements. We thank our colleagues at the Research Center for Environmental Changes (Academia Sinica, Taiwan) and the State Key Laboratory of Marine Environmental Science (Xiamen University, China) for their help in cruise participation and assistance. We especially thank Hongjie Wang, Wei Qian, and Wenping Jing for TSM and Chl $a$ samplings and measurements, and Jing Lin for nutrient measurement. We also thank Fuh-Kwo Shiah for providing the fluorometer and incubation instrument. This work was supported by the National Science Council of Taiwan and the National Natural Science Foundation of China.

Edited by: C.-K. Kang

\section{References}

Arrigo, K. R.: Marine microorganisms and global nutrient cycles, Nature, 437, 349-355, 2005.

Cao, X., Song, C., and Zhou, Y.: Limitations of using extracellular alkaline phosphatase activities as a general indicator for describing $\mathrm{P}$ deficiency of phytoplankton in Chinese shallow lakes, J. Appl. Phycol., 22, 33-41, 2010.

Chai, C., Yu, Z., Song, X., and Cao, X.: The status and characteristics of eutrophication in the Yangtze River (Changjiang) Estuary and the adjacent East China Sea, China, Hydrobiologia, 563, 313-328, 2006.

Chen, C. T. A.: The Kuroshio intermediate water is the major source of nutrients on the East China Sea continental shelf, Oceanol Acta, 19, 523-527, 1996.

Chen, C. T. A.: The Three Gorges Dam: Reducing the upwelling and thus productivity in the East China Sea, Geophys. Res. Lett., 27, 381-384, 2000.

Chen, C. T. A., Ruo, R., Paid, S. C., Liu, C. T., and Wong, G. T. F.: Exchange of water masses between the East China Sea and the Kuroshio off northeastern Taiwan, Cont. Shelf Res., 15, 19-39, 1995.

Chen, Y. L. L., Chen, H. Y., Lee, W. H., Hung, C. C., Wong, G. T., and Kanda, J.: New production in the East China Sea, comparison between well-mixed winter and stratified summer conditions, Cont. Shelf Res., 21, 751-764, 2001.

Chen, Y. L. L., Chen, H. Y., Gong, G. C., Lin, Y. H., Jan, S., and Takahashi, M.: Phytoplankton production during a summer coastal upwelling in the East China Sea, Cont. Shelf Res., 24, 1321-1338, 2004.

Cloern, J. E.: The relative importance of light and nutrient limitation of phytoplankton growth: a simple index of coastal ecosystem sensitivity to nutrient enrichment, Aquat. Ecol., 33, 3-15, 1999.

Dortch, Q. and Whitledge, T. E.: Does nitrogen or silicon limit phytoplankton production in the Mississippi River plume and nearby regions?, Cont. Shelf Res., 12, 1293-1309, 1992.

Duhamel, S., Dyhrman, S. T., and Karl, D. M.: Alkaline phosphatase activity and regulation in the North Pacific Subtropical Gyre, Limnol. Oceanogr., 55, 1414-1425, 2010.

Dyhrman, S. T. and Ruttenberg, K. C.: Presence and regulation of alkaline phosphatase activity in eukaryotic phytoplankton from the coastal ocean: Implications for dissolved organic phosphorus remineralization, Limnol. Oceanogr., 51, 1381-1390, 2006.

Fisher, T. R., Peele, E. R., Ammerman, J. W., and Harding, L. W.: Nutrient limitation of phytoplankton in Chesapeake Bay, Mar. Ecol.-Prog. Ser., 82, 51-63, 1992. 
Galloway, J. N., Dentener, F. J., Capone, D. G., Boyer, E. W., Howarth, R. W., Seitzinger, S. P., Asner, G. P., Cleveland, C. C., Green, P. A., Holland, E. A., Karl, D. M., Michaels, A. F., Porter, J. H., Townsend, A. R., and Vorosmarty, C. J.: Nitrogen cycles: past, present, and future, Biogeochemistry, 70, 153-226, 2004.

Geider, R. and La Roche, J.: Redfield revisited: variability of $\mathrm{C}: \mathrm{N}: \mathrm{P}$ in marine microalgae and its biochemical basis, Eur. J. Phycol., 37, 1-17, 2002.

Gong, G. C., Lee Chen, Y. L., and Liu, K. K.: Chemical hydrography and chlorophyll a distribution in the East China Sea in summer: implications in nutrient dynamics, Cont. Shelf Res., 16, 1561-1590, 1996.

Harrison, P. J., Hu, M. H., Yang, Y. P., and Lu, X.: Phosphate limitation in estuarine and coastal waters of China, J. Exp. Mar. Biol. Ecol., 140, 79-87, 1990.

Harrison, P. J., Yin, K., Lee, J. H. W., Gan, J., and Liu, H.: Physicalbiological coupling in the Pearl River Estuary, Cont. Shelf Res., 28, 1405-1415, 2008.

Hoppe, H. G.: Phosphatase activity in the sea, Hydrobiologia, 493, 187-200, 2003.

Howarth, R. W. and Marino, R.: Nitrogen as the limiting nutrient for eutrophication in coastal marine ecosystems: Evolving views over three decades, Limnol. Oceanogr., 51, 364-376, 2006.

Hsiao, S. S. Y., Hsu, T. C., Liu, J. W., Xie, X. B., Zhang, Y., Lin, J., Wang, H. J., Yang, J. Y., Hsu, S. C., Dai, M., and Kao, S. J.: Nitrification and its oxygen consumption along the turbid Changjiang River plume, Biogeosciences Discuss., 10, 86858713, doi:10.5194/bgd-10-8685-2013, 2013.

Hu, M. H., Yang, Y. P., and Harrision, P. J.: Limitation of phosphorus on phytoplankton growth in the Yangtze Estuary, Acta Oceanol. Sin., 11, 439-443, 1989 (in Chinese).

Huang, B., Ou, L., Hong, H., Luo, H., and Wang, D.: Bioavailability of dissolved organic phosphorus compounds to typical harmful dinoflagellate Prorocentrum donghaiense Lu, Mar. Pollut. Bull., 51, 838-44, 2005.

Hung, J. J., Chen, C. H., Gong, G. C., Sheu, D. D., and Shiah, F. K.: Distributions, stoichiometric patterns and cross-shelf exports of dissolved organic matter in the East China Sea, Deep-Sea Res. Pt. II, 50, 1127-1145, 2003.

Jickells, T. D.: Nutrient biogeochemistry of the coastal zone, Science, 281, 217-222, 1998.

Kondo, M.: Oceanographic investigation of fishing grounds in the East China Sea and Yellow Sea - Part I. Characteristics of the mean temperature and salinity distributions measured at $50 \mathrm{~m}$ and near the bottom, Bull. Sekai Reg. Fish. Lab., 62, 19-55, 1985 (in Japanese with English abstract).

Krom, M. D., Kress, N., Brenner, S., and Gordon, L. I.: Phosphorus limitation of primary productivity in the eastern Mediterranean Sea, Limnol. Oceanogr., 36, 424-432, 1991.

Lie, H. J., Cho, C. H., Lee, J. H., and Lee, S.: Structure and eastward extension of the Changjiang River plume in the East China Sea, J Geophys. Res.-Oceans (1978-2012), 108, C3, 2003.

Liu, H. C., Gong, G. C., and Chang, J.: Lateral water exchange between shelf-margin upwelling and Kuroshio waters influences phosphorus stress in microphytoplankton, Mar. Ecol.-Prog. Ser., 409, 121-130, 2010.

Liu, H. C., Shih, C. Y., Gong, G. C., Ho, T. Y., Shiah, F. K., Hsieh, C. $\mathrm{H}$., and Chang, J.: Discrimination between the influences of river discharge and coastal upwelling on summer microphytoplankton phosphorus stress in the East China Sea, Cont. Shelf Res., 60, 104-112, 2013.

Liu, L., Zhou, J., Zheng, B., Cai, W., Lin, K., and Tang, J.: Temporal and spatial distribution of red tide outbreaks in the Yangtze River Estuary and adjacent waters, China, Mar. Pollut. Bull., 72, 213 221, 2013.

Liu, S. M., Hong, G.-H., Zhang, J., Ye, X. W., and Jiang, X. L.: Nutrient budgets for large Chinese estuaries, Biogeosciences, 6 , 2245-2263, doi:10.5194/bg-6-2245-2009, 2009.

Lomas, M. W., Burke, A. L., Lomas, D. A., Bell, D. W., Shen, C., Dyhrman, S. T., and Ammerman, J. W.: Sargasso Sea phosphorus biogeochemistry: an important role for dissolved organic phosphorus (DOP), Biogeosciences, 7, 695-710, doi:10.5194/bg-7695-2010, 2010.

Mackey, K. R., Mioni, C. E., Ryan, J. P., and Paytan, A.: Phosphorus cycling in the red tide incubator region of Monterey Bay in response to upwelling, Front Microbiol., 3, 33, 2012.

Mather, R., Reynolds, S., Wolff, G., Williams, R. G., Torres-Valdes, S., Woodward, E. M. S., Landolfi, A., Pan, X., Sanders, R. W., and Achterberg, E.: Phosphorus cycling in the North and South Atlantic Ocean subtropical gyres, Nat. Geosci., 1, 439 443, 2008

Ou, L., Wang, D., Huang, B., Hong, H., Qi, Y., and Lu, S.: Comparative study of phosphorus strategies of three typical harmful algae in Chinese coastal waters, J. Plankton Res., 30, 1007-1017, 2008.

Parsons, T. R., Maita, Y., and Lalli, C. M.: A manual of chemical and biological methods for seawater analysis, Pergamon Press, Oxford, 1984

Pei, S., Shen, Z., and Laws, E. A.: Nutrient dynamics in the upwelling area of Changjiang (Yangtze River) Estuary, J. Coastal Res., 25, 569-580, 2009.

Perry, M. J.: Alkaline phosphatase activity in subtropical Central North Pacific waters using a sensitive fluorometric method, Mar. Biol., 15, 113-119, 1972.

Raymont, J. E. G.: Plankton and Productivity in the Oceans, Vol. 1. Phytoplankton 2nd Edn., Pergamon Press, Oxford, 1980.

Redfield, A. C.: The biological control of chemical factors in the environment, Am Sci. A, 46, 230-221, 1958.

Shen, L., Xu, H., Guo, X., and Li, M.: Characteristics of large-scale harmful algal blooms (HABs) in the Yangtze River Estuary and the adjacent East China Sea (ECS) from 2000 to 2010, J. Environ. Prot., 2, 1285-1294, 2011.

Shen, Z. L. and Liu, Q.: Nutrients in the Changjiang River, Environ. Monit. Assess.,153, 27-44, 2009.

Sylvan, J. B., Dortch, Q., Nelson, D. M., Maier Brown, A. F., Morrison, W., and Ammerman, J. W.: Phosphorus limits phytoplankton growth on the Louisiana shelf during the period of hypoxia formation, Environ. Sci. Technol., 40, 7548-7553, 2006.

Tang, D., Di, B., Wei, G., Ni, I. H., and Wang, S.: Spatial, seasonal and species variations of harmful algal blooms in the South Yellow Sea and East China Sea, Hydrobiologia, 568, 245-253, 2006.

Turner, R. E. and Rabalais, N. N.: Nitrogen and phosphorus phytoplankton growth limitation in the northern Gulf of Mexico, Aquat. Microb. Ecol., 68, 159-169, 2013.

Van Wambeke, F., Christaki, U., Giannakourou, A., Moutin, T., and Souvemerzoglou, K.: Longitudinal and vertical trends of bacterial limitation by phosphorus and carbon in the Mediterranean Sea, Microb. Ecol., 43, 119-133, 2002. 
Varkitzi, I., Pagou, K., Graneli, E., Hatzianestis, I., Pyrgaki, C., Pavlidou, A., Montesanto, B., and Economou-Amilli, A.: Unbalanced N:P ratio and nutrient stress controlling growth and toxin production of the harmful dinoflagellate Prorocentrum lima (Ehrenberg) Dodge, Harmful Algae, 9, 304-311, 2010.

Vaulot, D., Lebot, N., Marie, D., and Fukai, E.: Effect of phosphorus on the Synechococcus cell cycle in surface Mediterranean waters during summer, Appl. Environ. Microb., 62, 2527-2533, 1996.

Wang, B.: Cultural eutrophication in the Changjiang (Yangtze River) plume: History and perspective, Estuar. Coast. Shelf S., 69, 471-477, 2006.

Wang, B. D., Wang, X. L., and Zhan, R.: Nutrient conditions in the Yellow Sea and the East China Sea, Estuar. Coast. Shelf S., 58, 127-136, 2003.

Welschmeyer, N. A.: Fluorometric analysis of chlorophyll a in the presence of chlorophyll $b$ and pheopigments, Limnol. Oceanogr., 39, 1985-1992, 1994.

Wong, G. T. F., Gong, G. C., Liu, K. K., and Pai, S. C.: 'Excess Nitrate'in the East China Sea, Estuar. Coast. Shelf S., 46, 411418, 1998.

Yang, D., Yin, B., Liu, Z., Bai, T., Qi, J., and Chen, H.: Numerical study on the pattern and origins of Kuroshio branches in the bottom water of southern East China Sea in summer, J. Geophys. Res.-Oceans (1978-2012), 117, C2, 2012.
Yang, D., Yin, B., Sun, J., and Zhang, Y.: Numerical study on the origins and the forcing mechanism of the phosphate in upwelling areas off the coast of Zhejiang province, China in summer, J. Mar. Syst., 123-124, 1-18, 2013.

Yu, Y., Song, J., Li, X., Yuan, H., and Li, N.: Distribution, sources and budgets of particulate phosphorus and nitrogen in the East China Sea, Cont. Shelf Res., 43, 142-155, 2012.

Zhang, J., Liu, S. M., Ren, J. L., Wu, Y., and Zhang, G. L.: Nutrient gradients from the eutrophic Changjiang (Yangtze River) Estuary to the oligotrophic Kuroshio waters and re-evaluation of budgets for the East China Sea Shelf, Prog. Oceanogr., 74, 449478, 2007.

Zhao, D. Z., Zhao, L., Zhang, F. S., and Zhang, X. Y.: Temporal occurrence and spatial distribution of red tide events in China's coastal waters, Hum. Ecol. Rusk Assess., 10, 945-957, 2004.

Zhou, M.: Environmental settings and harmful algal blooms in the sea area adjacent to the Changjiang River Estuary, Coastal Environmental and Ecosystem Issues of the East China Sea, 133-149, 2010.

Zhou, M. J., Shen, Z. L., and Yu, R. C.: Responses of a coastal phytoplankton community to increased nutrient input from the Changjiang (Yangtze) River, Cont. Shelf Res., 28, 1483-1489, 2008. 